\title{
KEPEMIMPINAN LOKAL DAN KEHIDUPAN SOSIAL POLITIK PEREMPUAN DI DUA DESA BALI AGA KABUPATEN BULELENG
}

\author{
Ni Wayan Arini \\ Pendidikan Guru Sekolah Dasar, Fakultas IImu Pendidikan \\ Universitas Pendidikan Ganesha Singaraja-Bali
}

wayanarini@yahoo.co.id

\begin{abstract}
Abstrak
Penelitian ini bertujuan (1) menganalisis strategi pemimpin lokal melibatkan perempuan pada bidang sosial dan politik dalam institusi keluarga, masyarakat, dan lembaga politik di Desa Julah, Desa Tigawasa sebagai Desa Bali Aga di Kabupaten Buleleng, (2) menganalisis hambatan dan solusi pemimpin lokal melibatkan perempuan pada bidang sosial politik dalam institusi keluarga, masyarakat dan politik di Desa Julah, Desa Tigawasa sebagai Desa Bali Aga di Kabupaten Buleleng, dan (3) menganalisis pendidikan politik yang ideal dikehendaki oleh perempuan pascaotonomi di Desa Julah, Desa Tigawasa sebagai Desa Bali Aga di Kabupaten Buleleng. Penelitian ini adalah penelitian etnografis naturalisitik untuk mendeskripsikan secara aktual, faktual, alamiah, dan holistik tentang keterlibatan perempuan dalam bidang sosial politik. Subjek penelitian ini adalah prajuru desa pakraman, kepala desa, tokoh masyarakat, teruna-teruni, PKK, dan anggota masyarakat yang ditentukan secara purposive. Data dikumpulkan dengan prinsip "human instrument", yaitu peneliti merupakan instrumen peneliti yang utama, di samping menggunakan kuesioner. Data yang terkumpul dianalisis dengan analisis deskriptif. Hasil penelitian menunjukkan bahwa pemimpin lokal desa prakraman Julah dan Tigawasa menerapkan beberapa strategi untuk melibatkan perempuan dalam bidang sosial politik. Penerapan strategi ini berjalan lancar, sehingga perempuan memperoleh kesempatan belajar berpolitik melalui berbagai organisasi yang ada di desa. Atas dasar itu, disarankan agar pemimpin lokal memberikan kontribusi terhadap kehidupan sosial politik perempuan di dua Desa Bali Aga di Kabupaten Buleleng dalam upaya memberdayakan perempuan yang berwawasan dan berkeadilan gender.
\end{abstract}

Kata kunci: kepemimpinan lokal, sosial politik, perempuan

\begin{abstract}
The purposes of study were to analyze (1) the strategy of local leaders involving the females in social and political fields in family institution, society, and political institution in Julah and Tigawasa villages as Bali Aga villages, Buleleng regency, (2) the difficulties and solutions of local leaders involving the females in social and political fields in family institution, society, and political institution in Julah and Tigawasa villages as Bali Aga villages, Buleleng regency, (3) the ideal political expected by the females, postautonomy in the two villages, Buleleng regency. The research used etnografic - naturalistic design in describing the
\end{abstract}


involvement of the females in actual, factual, and holistic ways. The subjects were prajuru desa pakraman, the village head, society leaders, youth, female's organization, the society members which were determenid purposively. The data were collected by the use of human instrument principle, namely, the researcher was the main instrument in the research and questionaire. The collected data were analyzed descriptively - qualitatively. The research result showed that the local leaders of Julah and Tigawasa villages application of the strategies ran well, so thet the females got the opportunities of learning polotics through varions organizations in the villages. It is suggested that the local leaders give contribution in the females' social - political life in the two villages of Bali Aga, Buleleng regency in an effort to involve the females having a wider horizon in gender fairnnes.

Key words: local leader, social-political, female

\section{PENDAHULUAN}

Dewasa ini, perempuan tidak lagi hanya berperan sebagai ibu rumah tangga yang menjalankan fungsi reproduksi, mengurus anak dan suami, atau melakukan pekerjaan domestik lainnya. Perempuan sudah aktif berperan di berbagai bidang kehidupan, baik sosial, ekonomi, maupun politik. Bahkan, pekerjaan-pekerjaan tertentu, yang sepuluh atau dua puluh tahun lalu hanya pantas dilakukan laki-laki, saat ini pekerjaan tersebut sudah bisa dan biasa dilakukan oleh perempuan, termasuk pada pekerjaan kasar sekalipun.

Dalam rangka meningkatkan kesetaraan dan pembangunan yang sensitif gender pemerintah telah mengeluarkan Instruksi Presiden No. 20 Tahun 2000 tentang Pengarusutamaan Gender dalam pembangunan sosial dan munculnya berbagai kegiatan yang berbasis gender, termasuk penyusunan statistik dan indikator gender yang pertama kali dirilis BPS pada tahun 2000, yang menunjukkan antara rendahnya representasi perempuan dalam DPR (8,8\%), MPR $(9,1 \%)$, anggota DPA (2,7\%), hakim agung $(13 \%)$, kepala desa/lurah $(2,3 \%)$ dan berkedudukan dalam jabatan struktural kepegawaian $(15,2 \%)$, padahal rasio penduduk laki-laki, yaitu 99,1, yang berarti dari 100 penduduk perempuan terdapat 99 penduduk laki-laki (Nugroho, 2008). Di samping itu, berdasarkan data dari KPU Provinsi Bali (2009), anggota DPRD wanita Provinsi Bali periode 2004-2009 berjumlah 4 orang $(7,3 \%)$ dari 55 orang anggota DPR. Data ini menunjukkan bahwa persentase keterlibatan perempuan dalam dunia politik sangat kecil dibandingkan keterlibatan laki-laki.

Di antara sektor-sektor publik yang telah dimasuki wanita, sektor politik merupakan hal yang sangat menarik sekaligus sangat penting. Menarik karena secara historis memang sangat kecil keterlibatan perempuan dalam politik praktis. Sangat penting karena sesungguhnya keterlibatan wanita dalam sektor politik dapat berpengaruh sangat besar pada kebijakan yang diambil, khususnya dalam kaitannya dengan peran perempuan secara menyeluruh. Hal ini dapat terjadi karena suara-suara perempuan lebih nyaring terdengar bila disuarakan oleh anggota parlemen, misalnya.

Seiring dengan perkembangan
jaman, tingkat modernisasi dan Jurnal IImu Sosial dan Humaniora | 411 
globalisasi informasi, keberhasilan gerakan emansipasi perempuan, sikap, serta peran perempuan, khususnya pandangan tentang dunia politik mulai mengalami pergeseran. Perempuan tidak lagi hanya berperan sebagai ibu rumah tangga yang menjalankan fungsi reproduksi, mengurus anak dan suami, atau melakukan pekerjaan domestik lainnya. Perempuan sudah aktif berperan di berbagai bidang kehidupan, baik sosial, ekonomi, maupun politik.

Pengamatan awal menunjukkan bahwa kedudukan perempuan di Desa Pakraman Julah sebagai Desa Bali Aga sangat penting. Kedudukan seorang lakilaki sebagai krama negak harus didampingi oleh seorang perempuan sebagai suami istri. Seandainya seorang laki-laki kehilangan seorang istri karena cerai atau meninggal, maka laki-laki kehilangan statusnya sebagai krama negak. Krama di desa tersebut memiliki pemimpin adat dan agama yang disebut kubayan atau bau luh (perempuan) yang memiliki kedudukan yang sama-sama terhormat. Bahkan dalam suatu ritual di pura, istri kubayan dan bau luh wajib memainkan tari sakral, yaitu rejang sebagai persyaratan sahnya suatu ritual.

Masyarakat desa Tigawasa mempunyai mata pencaharian sebagai pengrajin, khususnya kerajinan bambu dengan berbagai motif. Dalam konteks pekerjaan, terdapat pemilahan yang dilakukan oleh laki-laki dan perempuan, yakni laki-laki menyiapkan bahan-bahan anyaman bambu, sedangkan yang perempuan menganyam bambu.

Pembagian kerja secara gender yang mengasosiasikan perempuan di arena domestik dan laki-laki di arena publik mengakibatkan terjadinya perbedaan status dan peran. Hal ini terjadi karena perempuan hanya bertanggung jawab terhadap pekerjaan rumah tangga, meliputi melahirkan, membesarkan anak, memasak untuk keluarga, dan melayani suami. Sementara laki-laki terlibat langsung dengan masalah-masalah sosial, ekonomi, dan politik, serta pekerjaan yang dianggap sebagai kegiatan publik. Akibatnya, kedudukan perempuan menjadi sangat lemah pada bidangbidang yang dimasuki oleh laki-laki.

Pada awalnya studi tentang perempuan cenderung melihat wanita sebagai entitas yang tidak terintegrasi dengan aspek-aspek yang lainnya. Penelitian ini memusatkan perhatian kepada perempuan dengan anggapan bahwa munculnya permasalahan perempuan disebabkan oleh kurang menyatunya mereka secara maksimal dalam pembangunan, khususnya pembangunan politik. Oleh karena itu, penelitian ini dipusatkan pada persoalan perempuan dengan menggunakan kerangka perbedaan seksual, yakni kerangka perbedaan biologis antara lakilaki dengan perempuan. Penelitian semacam ini pernah dilakukan oleh beberapa peneliti, misalnya : Muryani (1985); Suratiyah (1990); dan Aryani \& Wiasti (1991). Hasil penelitian tersebut hanya mampu menunjukkan alasan wanita bekerja atau memaparkan sumbangan wanita terhadap ekonomi rumah tangga.

Cara-cara semacam ini ternyata tidak banyak membantu memecahkan permasalahan perempuan. Oleh karena itu, dalam perkembangan selanjutnya, studi perempuan dititikberatkan kepada sistem dan struktur masyarakat yang didasarkan kepada analisis hubungan gender. Analisis ini memerhatikan 
persoalan hubungan sosial budaya lakilaki dan wanita, suatu hubungan yang menunjukkan wanita secara sistematis lebih rendah daripada laki-laki (Mosse, 1996). Gender diartikan sebagai konstruksi sosiokultural yang membedakan karakteristik maskulin dan feminin. Dengan kata lain, kategori maskulin atau feminim itu bergantung pada konteks sosial budaya setempat.

Beberapa penelitian yang berperspektif gender sudah pernah dilakukan. Gandarsih (1986) mengatakan bahwa dalam menanggapi peran ganda wanita dalam suatu masyarakat sangat penting untuk dipahami nilai-nilai yang dianut oleh masyarakat yang bersangkutan. Sementara di Bali, penelitian tentang nilai-nilai budaya lokal berpengaruh terhadap keterlibatan wanita dalam sektor ekonomi sudah pernah dilakukan sebelumnya. Misalnya, penelitian Ariani (1986) menunjukkan bahwa nilai-nilai agama Hindu dan status sosial wanita berpengaruh terhadap pola kerja. Untuk itu, penelitian ini berusaha memerhatikan aspek yang cenderung diabaikan tersebut.

Pengarusutamaan gender (PUG) bertalian dengan kondisi nyata yang dihadapi perempuan pada tataran struktur sosial, yakni subordinasi oleh laki-laki sehingga menimbulkan kondisi ketidaksetaraan dan ketidakadilan. Kondisi inilah menimbulkan gerakan Pengarusutamaan Gender. Cattleya (2006) yang secara lugas memberikan definisi tentang PUG sebagai berikut.

PUG adalah strategi, upaya, pendekatan, atau cara yang diakui secara global untuk mencapai tujuan kesetaraan gender. PUG bukan tujuan, melainkan cara untuk memastikan agar perspektif gender dan kesetaraan gender menjadi fokus semua proses dan siklus perencanaan, penyusunan kebijakan, program/proyek/kegiatan, penelitian, advokasi, perundangan, dan alokasi sumber daya.

Berdasarkan INPRES Nomor 9 Tahun 2000, pemerintah Indonesia telah mengeluarkan kebijakan nasional tentang Pengarusutamaan Gender (PUG) sebagai bagian dari pembangunan Pemberdayaan Perempuan Indonesia. Dalam INPRES tersebut ditegaskan bahwa PUG adalah strategi yang dilakukan secara nasional dan sistematis untuk mencapai kesetaraan dan keadilan gender dalam sejumlah aspek kehidupan manusia melalui kebijakan dan program yang memerhatikan pengalaman, pelaksanaan, dan evaluasi dari seluruh kebijakan dan program di berbagai bidang kehidupan dan pembangunan.

Dengan adanya kesetaraan gender, upaya pemberdayaan perempuan semakin digalakkan. Dengan keterbatasannya, perempuan dapat ikut serta berperan sebagai pemimpin meskipun lingkup desa pakraman atau banjar. Dengan kata lain, wanita siap "ngayah" di lingkungan desa pakraman atau banjar dengan pengorbanan pikiran, tenaga, materi, serta waktu demi kepentingan lingkungannya tanpa imbalan, yang merupakan salah satu kearifan lokal masyarakat Bali.

Berdasarkan persoalan di atas, maka penelitian ini dilaksanakan dengan tujuan untuk: 1) menganalisis strategi pemimpin lokal melibatkan kaum perempuan pada bidang sosial politik dalam institusi keluarga, masyarakat, dan politik di Desa Julah, Desa Tigawasa sebagai Desa Bali Aga di 
Kabupaten Buleleng, 2) menganalisis hambatan dan solusi pemimpin lokal melibatkan kaum perempuan pada bidang sosial politik dalam institusi keluarga, masyarakat, dan politik di Desa Julah, Desa Tigawasa sebagai Desa Bali Aga di Kabupaten Buleleng, dan 3) menganalisis pendidikan politik yang ideal dikehendaki oleh kaum perempuan pascaotonomi di Desa Julah, Desa Tigawasa sebagai Desa Bali Aga di Kabupaten Buleleng.

\section{METODE PENELITIAN}

Penelitian ini menggunakan rancangan penelitian kualitatif bersifat naturalistik dan etnografis, sehingga penekanannya bukan pada pengukuran, melainkan pada upaya mendeskripsikan secara aktual, faktual, alamiah, holistik, dan emik tentang eksistensi perempuan dalam bidang politik. Penelitian ini dilakukan pada desa pakraman Bali Aga yaitu Desa Pakraman Julah dan Desa Pakraman Tigawasa di Kabupaten Buleleng dengan subjek penelitian prajuru desa pakraman, kepala desa, pengurus PKK, teruna-teruni, dan anggota masyarakat, yang ditentukan secara purposive.

Pengumpulan data dalam penelitian menganut prinsip "human instrument" yaitu peneliti merupakan instrumen penelitian yang utama Di samping itu, pengumpulan data juga dilakukan melalui wawancara, observasi, dan kuesioner. Wawancara digunakan untuk menjaring data yang berkaitan dengan keberadaan perempuans menurut peraturan perundang-undangan dalam bidang politik, strategi perempuan untuk memperoleh keadilan dalam bidang politik, dan tantang yang dihadapi perempuan dalam bidang politik. Observasi dilaksanakan untuk mengamatai, mencatat, dan mendokumentasikan rutinitas sosial budaya yang terkait dengan aktivitas politik perempuan di dua Desa Bali Aga. Kuesioner digunakan untuk kepentingan jastifikasi dan validasi data yang telah terkumpul. Data yang telah terkumpul dianalisis menggunakan teknik analisis data secara kualitatif dengan berbagai kegiatan yaitu: (1) reduksi data, (2) display data, (3) interpretasi data, (4) verifikasi data, (5) penarikan simpulan (Miles dan Huberman, 1992).

\section{HASIL PENELITIAN DAN PEMBAHASAN HASIL PENELITIAN}

\section{Strategi Pemimpin Lokal Melibatkan Perempuan pada Bidang Sosial dan Politik dalam Institusi Keluarga, Masyarakat, dan Lembaga Politik}

Masyarakat desa pakraman Julah dan Tigawasa tergolong dalam kelompok masyarakat Bali Aga. Untuk menjalankan pemerintahan desa, kedua desa pakraman ini memiliki awig-awig desa. Bila dicermati isi awig-awig desa pakraman Julah dan Tigawasa tampak bahwa tidak membedakan laki-laki dan perempuan di dalam desa pakraman. Makna krama di dalam organisasi desa pakraman, khususnya dalam awig-awig adalah laki-laki dan perempuan, yaitu sebutan krama adat laki-laki (muani) dan krama adat perempuan (luh).

Dalam struktur pemerintahan ini, kaum laki-laki tetap menguasai seluruh struktur dan aktivitas pemerintahan yang memperoleh legitimasi dari kekuasaan raja yang telah didewakan oleh masyarakat Julah. Salah satu peranan menonjol yang dimiliki kaum 
perempuan Julah dalam sejarah awal perkembangan masyarakat Julah adalah dalam bidang perdagangan.

Menurut I Made Murtika (Prajuru

Desa Pakraman Tigawasa), kaum perempuan di desa Tigawasa dilibatkan dalam kehidupan sosial politik dengan memberdayakan atau mengoptimalkan organisasi perempuan yang telah ada di desa, memberikan kesempatan yang sama antara laki-laki dan perempuan untuk duduk dalam kepengurusan desa pakraman, memfasilitasi dan mendorong kaum perempuan untuk menjadi pemimpin, baik di tingkat lokal maupun dan di luar desanya, dan melakukan koordinasi dengan semua organisasi perempuan, baik di desa dinas maupun di desa pakraman.

Strategi di atas sesungguhnya menempatkan laki-laki dan perempuan dalam kedudukan yang seimbang. Peranan prajuru (pemimpin) desa pakraman dan kepala desa/lurah sangat penting dalam upaya memberdayakan kaum perempuan dewasa ini mengingat pemimpin dan keluarganya dapat menjadi teladan bagi warga atau krama desa dalam upaya memberdayakan kaum perempuan di desa. Keteladanan ini tidak saja bersifat pasif, melainkan juga aktif. Bendesa desa pakraman, kepala desa dinas, petugas kader desa, dan tokoh-tokoh masyarakat lainnya, serta keluarganya mempromosikan dan menyosialisasikan kepada masyarakat untuk menggerakkan kaum perempuan. Para prajuru desa pakraman dan kepala desa dapat menjadi sumber informasi bagi kaum perempuan. Para prajuru desa pakraman maupun desa dinas berkewajiban memberikan sosialisasi, promosi, bimbingan dan penyuluhan kepada warganya tentang aktivitas kaum perempuan. Kegiatan-kegiatan ini tidak hanya dilakukan para prajuru secara personal, tetapi juga berkoordinasi dan bekerja sama dengan kelompok pengerajin perempuan, posyandu, karang taruna, dan tokohtokoh masyarakat lainnya. Dalam kapasitasnya sebagai pemimpin desa, baik prajuru desa pakraman maupun desa dinas juga telah berupaya meminta penduduk yang memiliki usaha ekonomi kreatif untuk melibatkan kaum perempuan dalam usaha itu secara maksimal.

\section{Hambatan dan Solusi Pemimpin Lokal Melibatkan Perempuan pada Bidang Sosial Politik dalam Institusi Keluarga, Masyarakat dan Politik}

Secara historis, dapat dikatakan bahwa peranan politik kaum perempuan Julah dan Tigawasa sangat terbatas. Artinya, peranan politik perempuan tersubordinasi terhadap laki-laki. Dalam perjalanan sejarah desa pakraman Julah dan Tigawasa, kaum laki-lakilah yang paling berperan daripada kaum perempuan. Ini menunjukkan bahwa peranan politik perempuan terabaikan. Satu-satunya peranan menonjol perempuan julah yang tergambarkan di atas adalah dalam bidang perekonomian sebagai pedagang yang disebut sebagai wanigrami.

Demikian pula kedudukan
perempuan di desa pakraman Tigawasa, pada dasarnya tidak jauh berbeda dengan kedudukan perempuan di desa pakraman Julah. Desa pakraman Tigawasa menempatkan perempuan pada bidang-bidang yang sesuai dengan keperempuannya, seperti membuat banten, kerajinan 
rumah tangga, dan kegiatan domestik lainnya.

Kaum perempuan umumnya melaksanakan tugas-tugas domestik, seperti menyiapkan makanan untuk keluarga dan ternak, memberi makan ternak, mencuci pakaian untuk seluruh keluarga, menyiapkan upakara di lingkungan keluarga, merawat tanaman dan kebun, menyiapkan banten untuk kegiatan ritual di keluarga dan pura, menghaturka tari rejang di pura, membersihkan lingkungan rumah, berjualan ke pasar, memetik hasil pertanian, mengambil dan mengumpulkan air untuk kepentingan keluarga, dan sebagainya (Branson, 1988).

Dari uraian di atas jelaslah bahwa perbedaan kedudukan, peran dan tugas kaum laki-laki dan perempuan membawa implikasi kepada rendahnya tugas dan peran sosial politik perempuan dibandingkan dengan kaum laki-lakinya. Perempuan tidak memiliki peran sebagai pemimpin di masyarakat dan tidak ikut serta dalam pengambilan keputusan desa pakraman dan untuk kepentingan pura.

Berdasarkan hasil wawancara dengan I Made Murtika (Perbekel Desa Tigawasa) diketahui bahwa tidak ada hambatan dalam memberdayakan perempuan di Desa Tigawasa. Hal ini terjadi karena adanya kesadaran para perempuan dalam melaksanakan kewajibannya. Ini berarti bahwa perempuan telah mendapat perhatian di desa pakraman. Setiap kegiatan yang ada di desa Tigawasa selalu melibatkan luh lan muani (laki-laki dan perempuan). Namun, dalam mengambil pekerjaan disesuaikan dengan jenis pekerjaan yang pantas dikerjakan oleh kaum perempuan. Seperti yang dikemukakan oleh Ni Nyoman Pariastini (Ketua Kelompok Pengrajin Desa Tigawasa) bahwa dirinya sendiri dan perempuan Tigawasa pada umumnya tidak merasa disisihkan/dianaktirikan oleh pemimpin lokal, tetapi diberikan kesempatan yang sama untuk berkreasi. Sebagai bukti bahwa dirinya telah sampai ke tingkat nasional mewakili Buleleng untuk memperkenalkan kerajinan desa pakraman Tigawasa.

\section{Pendidikan Politik yang Ideal Dikehendaki oleh Perempuan Pascaotonomi \\ Dalam keluarga di desa} pakraman Julah dan Tigawasa memang diakui bahwa kedudukan suami sebagai kepala keluarga. Ini adalah konsekuensi diterapkannya hukum dan budaya kekerabatan yang bersifat patriarkat. Namun, dilihat secara politis sesungguhnya proses pendidikan yang berlangsung dalam lingkungan keluarga di Julah bersifat demokratis. Artinya, suami maupun istri memiliki kedudukan dan status yang sama sebagai kepala keluarga dalam lingkungan keluarganya sendiri. Ada konsekuensi lain dari praktik politik kepemimpinan keluarga seperti di atas, yaitu dalam pengambilan keputusan keluarga, suami istri memiliki kedudukan dan hak yang sama, baik yang menyangkut keputusan tentang penetapan tujuan-tujuan keluarga, pemanfaatan hasil nafkah keluarga, pemenuhan kebutuhan anak-anak termasuk kebutuhan pendidikannya, maupun dalam menetapkan pembagian kerja dan pola aktivitas keluarga.

Dalam hal pendidikan terhadap anak, umumnya kedua orang tua pada keluarga masyarakat Julah 
mengembangkan model pola asuh yang bersifat demokratis dan tidak membedakan karakteristik gender. Ini dibenarkan oleh beberapa anak SD dan SLTP di desa pakraman Julah dan Tigawasa bahwa kedua orang tuanya tidak terlalu mengatur mereka, tetapi juga tidak membebaskan mereka. Semua kebutuhan anak-anak, terutama kebutuhan sandang dan peralatan pendidikan, biasanya disampaikan kepada ibu dan harus mendapat persetujuan bapak, dan begitu pula sebaliknya. Keberhasilan pola asuh orang tua dalam pendidikan keluarga yang bersifat demokratis dan tidak bersifat bias gender tersebut memungkinkan tingkat pendidikan anakanak pada masyarakat di desa pakraman Julah dan Tigawasa seimbang antara anak laki-laki dan anak perempuan. Kondisi seperti ini telah memberikan kontribusi kepada peningkatan kesadaran politik pada generasi muda perempuan untuk turut berpartisipasi aktif secara politis bagi kepentingan desanya.Pendidikan politik kaum perempuan Julah dan Tigawasa di lingkungan desa pakraman ini diakui tidaklah diperoleh dari adanya ceramahceramah atau semacam dharma tula kepada kaum perempuan, melainkan melalui belajar secara partisipasif. Artinya, kaum perempuan Julah dan Tigawasa ikut terlibat aktif dalam peranan-peranan di desa pakraman atau pura. Dengan demikian, mereka menyadari kedudukan, status, tugas dan peran, hak-hak, kewajiban, kekuasaan dan wewenang, pembagian kerja, maupun hubungannya dengan komponen-komponen lain di desa pakraman dan pura. Perempuan Julah dan Tigawasa memulai belajar memerankan partisipasi sosial politiknya kepada desa pakraman dan pura melalui kedudukan dan statusnya sebagai anggota sekeha teruna-teruni.

Satu penghargaan yang diberikan kepada kelompok teruni adalah ketika menetapkan tugas yang akan memendak dan ngewaliang (mengambil dan mengembalikan) kulkul agung sebagai kelengkapan utama upacara. Petugas yang melakukan ini adalah seorang perempuan remaja yang orang tuanya telah menyelesaikan upacara daur kehidupan dan upacara pasca perkawinannya. Hal ini menunjukkan bahwa betapa tingginya nilai religius perempuan yang masih suci bagi kepentingan berlangsungnya upacara karena hanya perempuan remajalah yang boleh melakukan tugas ini. Bahkan kubayan dinyatakan tidak dapat memimpin upacara jika kulkul agung ini belum diambil oleh petugas perempuan remaja yang ditetapkan.

Ayahan tari rejang ini adalah wajib dilakukan pada saat upacara akan nyineb dan diyakini bahwa upacara tidak boleh diselesaikan tanpa adanya aturan tari rejang ini. Walaupun perempuan tidak berhak mengambil keputusan, ia tetap memiliki hak veto untuk kelangsungan proses upacara. Tanpa partisipasi perempuan ini diyakini pula proses upacara di pura tidak akan berlangsung secara sempurna bahkan dapat dianggap batal. Dilema yang terjadi di sini adalah antara nilai politis laki-laki dengan nilai religius perempuan yang dianggap memiliki nilai kehormatan yang sama oleh masyarakat. Secara keseluruhan, dalam partisipasinya kepada desa pakraman dan pura sesungguhnya amatlah sulit

Jurnal IImu Sosial dan Humaniora 417 
untuk mengatakan bahwa kedudukan perempuan tersubordinasi.

Pemerintah desa dinas dapat juga dijadikan wahana pendidikan politik bagi kaum perempuan julah. Melalui pemerintahan desa dinas inilah perempuan Julah dapat menunjukkan peranan dan partisipasi sosial politiknya, terutama ikut peduli dan mengabdi kepada kepentingan-kepentingan sosial dan politik yeng bersifat lebih luas daripada hanya sebatas kepentingankepentingan individu dan keluarga.

Ada beberapa sarana dan suborganisasi pemerintahan desa dinas yang dapat dijadikan wahana pendidikan politik bagi kaum perempuan Julah, antara lain melalui organisasi dan kegiatan PKK, kegiatan pos pelayanan terpadu, organisasi arisan kaum perempuan dan kegiatan simpan pinjam, organisasi karang taruna, satuan kompi hansip wanita, dan dalam struktur organisasi pemerintahan desa dinas.

Dari uraian di atas dapatlah disimpulkan bahwa berbagai strategi telah diterapkan oleh pemimpin lokal melibatkan perempuan pada bidang sosial dan politik dalam institusi keluarga, masyarakat, dan lembaga politik di Desa Julah, Desa Tigawasa, sehingga perempuan Julah dan Tigawasa memperoleh hak yang sama dalam pendidikan politik dilingkungan pemerintahan desa dinas melalui berbagai organisasi sosial di tingkat desa. Tidak ada hambatan yang berarti dalam pelibatan perempuan di bidang sosial politik dalam institusi keluarga, masyarakat dan politik di Desa Julah, Desa Tigawasa. Wanita dilibatkan dalam berbagai aktivitas sesuai dengan kemampuan yang dimilikinya dan kodratnya sebagai perempuan.

\section{PEMBAHASAN}

Memang diakui bahwa laki-laki Julah tidak mungkin memiliki kekuasaan politiknya di desa pakraman tanpa adanya ikatan perkawinan dengan perempuan (Atmadja, 1996). Ini berarti bahwa kehadiran perempuan dalam ikatan perkawinan telah memberikan kekuatan politik kepada kaum laki-laki dalam organisasi desa adatnya. Setelah kekuatan politik ini dimiliki oleh laki-laki, melalui konsep luan dan teben, kekuasaan itu akhirnya tetap dipertahankan untuk menjaga keseimbangan hubungan antara manusia dan manusia, manusia dan lingkungan, manusia dan Tuhan Namun, ada kepercayaan bahwa tidaklah mungkin kaum laki-laki Julah menyerahkan kekuasaan politiknya kepada perempuan. Jika ini dipaksakan, diyakini akan menimbulkan bahaya atau malapetaka. Dalam diri perempuan melekat unsur kekotoran. Kekuasaan yang mengandung unsur leteh tentu dapat menimbulkan malapetaka. Oleh karena itu, perempuan yang datang bulan (menstruasi) dinyatakan cuntaka dan tidak dibolehkan masuk ke wilayah pura dan tempat-tempat suci lainnya dan dilarang menyelenggarakan kegiatan upacara adat atau agama. Kenyataan seperti ini tampaknya berlaku secara umum bagi perempuan di Bali. Di sinilah letak ambivalensi nilai perempuan Julah dalam peranan politiknya. Di satu sisi, perempuan memberikan kekuatan politik itu kepada laki-laki dan melegitimasinya melalui ikatan perkawinan, tetapi akhirnya kekuasaan politik itu rela diserahkan

Jurnal IImu Sosial dan Humaniora| 418 
dari tangannya dan dipegang oleh lakilaki yang menjadi suaminya (Branson, 1988). Ini tidak berarti bahwa perempuan Julah tidak memiliki peran politik sama sekali di pura atau di desa adat. Bagaimanapun perempuan sebagai pendamping yang telah memberikan kekuasaan politik kepada laki-laki dapat membantu laki-laki dalam perannya sebagai pemimpin agama atau ritual.

Kondisi seperti di atas disimbolkan dengan baik lewat tarian sakral pada upacara ngusaba meras yang disebut dengan tari gayung. Pada tarian itu, kubayan istri menggunakan busana laki-laki dengan memakai destar menari tarian mengayuh lancang atau jukung. Tarian ini menggambarkan hubungan tolong- menolong antara lakilaki (kubayan lanang) dan perempuan (kubayan istri). Jadi, tarian ini melambangkan peran perempuan dalam memimpin upacara untuk membantu suaminya yang perlu beristirahat. Perempuan mendapat posisi terhormat dalam pelaksanaan upacara di desa pakraman tersebut. Tanpa perempuan, pelaksanaan upacara belum selesai. Perempuan berkedudukan sebagai subordinasi dalam proses pendidikan politik di tingkat lingkungan dan atau kepentingan desa pakraman dan pura. Perempuan Julah dan Tigawasa memulai belajar memerankanpartisipasi sosial politiknya kepada desa pakraman dan pura melalaui kedudukan dan statusnya sebagai anggota sekeha teruan-teruni.

Masyarakat Julah dan Tigawasa memerhatikan aspek kemandirian desa pakraman pada dimensi politik, ekonomi, sosial budaya dan keamanan, seperti penegakan prinsip rule of law, pelaksanaan hak azasi manusia, demokrasi dan keterbukaan. Masyarakat di kedua desa tersebut benar-benar sebagai masyarakat otonom yang mampu mandiri. Realita kemandirian masyarakat pakraman Julah dan Tigawasa merupakan perwujudan cita-cita masyarakat madani yang dilandasi oleh pandangan hidup tri hita karana. Cita-cita masyarakat madani desa Julah mempunyai relevansi yang kuat dengan cita-cita masyarakat madani Indonesia yang berorientasi pada kemandirian masyarakat sipil (civil society) dalam berbagai dimensi kehidupan menuju terwujudnya masyarakat Pancasila.

\section{PENUTUP}

Kaum perempuan di desa Julah dan Tigawasa dilibatkan dalam kehidupan soisal politik dengan memberdayakan atau mengoptimalkan organisasi perempuan yang telah ada di desa, memberikan kesempatan yang sama antara laki-laki dan perempuan untuk duduk dalam kepengurusan desa pakraman, memfasilitasi dan mendorong kaum perempuan menjadi pemimpin, baik di tingkat lokal maupun dan di luar desanya sendiri, dan melakukan koordinasi dengan semua organisasi perempuan, baik di desa dinas maupun di desa pakraman.

Memberdayakan perempuan di kedua desa tersebut tidak mengalami hambatan. Hal ini disebabkan oleh adanya kesadaran para perempuan dalam melaksanakan kewajibannya. Setiap kegiatan yang ada di desa selalu melibatkan luh lan muani (laki-laki dan perempuan). Namun, pekerjaan yang diambil oleh pihak perempuan disesuaikan dengan jenis pekerjaan 
yang mampu dikerjakan oleh kaum perempuan. Jadi, perempuan tidak merasa disisihkan/dianaktirikan oleh pemimpin lokal, tetapi diberikan kesempatan yang sama untuk berkreasi. Sebagai bukti bahwa banyak kaum perempuan telah mampu mengukir prestasi sampai ke tingkat nasional mewakili Buleleng untuk memperkenalkan potensi perempuan atau desa pakraman.

Pendidikan politik dalam keluarga masyarakat desa Julah dan Tigawasa menerapkan pola dan mekanisme pendidikan demokrasi dalam keluarga. Artinya, setiap anggota keluarga mengetahui dan menghormati struktur keluarga dengan kedudukan, status, dan peran masing-masing dalam struktur pemerintahan keluarga tersebut. Perempuan mulai belajar memerankan partisipasi sosial politiknya dalam desa pakraman dan pura melalui kedudukan dan statusnya sebagai anggota sekehe teruna-teruni. Organisasi ini diikuti setelah perempuan menginjak fase remaja. Tugas sekehe ini umumnya adalah membantu krama negak khususnya dan masyarakat Julah pada umumnya dalam pengabdian kepada kepentingan-kepentingan pura dan desa pakraman. Ada beberapa sarana dan suborganisasi pemerintahan desa dinas yang dapat dijadikan wahana pendidikan politik bagi kaum perempuan Julah dan Tigawasa, antara lain melalui struktur organisasi dan aktivitas kegiatan PKK, kegiatan posyandu, organisasi arisan kaum perempuan dan kegiatan simpan pinjam, organisasi karang taruna, satuan kompi hansip perempuan, dan dalam struktur organisasi pemerintahan desa dinas.
Berdasarkan hasil penelitian, disarankan agar pemimpin lokal Desa Julah, Desa Tigawasa sebagai Desa Bali Aga di Kabupaten Buleleng berupaya memberdayakan kaum perempuan di desa pakraman dan desa dinas masingmasing, sehingga secara bertahap, kaum perempuan dapat berkiprah dalam bidang sosial polotik. Pemimpin lokal Desa Julah, Desa Tigawasa juga hendaknya senantiasa memberikan informasi kepada kaum perempuan tentang aktivitas yang seharusnya dapat dilaksanakan oleh kaum perempuan melalui sosialisasi, promosi, bimbingan, dan penyuluhan. Pemimpin lokal Desa Julah, Desa Tigawasa disarankan agar berupaya meminta penduduk yang memiliki usaha kreatif agar melibatkan kaum perempuan secara maksimal dalam usahanya. Dengan demikian, revitalisasi nilai-nilai sosial budaya di tengah dahsyatnya tuntutan kesetaraan dan keadilan gender dapat terwujud.

\section{DAFTAR PUSTAKA}

Anderson, Margaret L. 1983. Thinking about Women: Sosiological and fesimist perspectives. New York: Macmillan Publishers.

Ariani, I G. A. 1986. Pengaruh Pariwisata terhadap Status Sosial Wanita Bali dalam Pembangunan: Studi Kasus di Desa Mas, Gianyar, Bali, Tesis S-2 IPB. Tidak Diterbitkan.

Atmadja, N. B. 2007 Permasalahan dan Tantangan Pengarusutamaan Gender dalam Bidang IPTEKS (Makalah) Disampaikan dalam Diskusi Permasalahan dan Tantangan dalam Pengarusutamaan Gender yang diselenggarakan oleh Kementrian Negara Ristek Bekerjasama

Jurnal IImu Sosial dan Humaniora| 420 
dengan Undiksha, pada 4 Juni Tahun 2007.

Cattley, L. 2006. "Pelembagaan Akuntabilitas Pengarusutamaan Gender: Bukan Sesuatu yang Mustahil" .Jurnal Perempuan 50. Halaman 45-58.

Chafetz, Janet Salzman. 1991. The Gender Devision at Labour and the Reproduction of Female Disadvantage : Toward an Integrated Theory

Dahlan, Juwariah. 1992. Wanita dalam Perspektif Agama Hindu, dalam Mayshur Amin dan Masuchah(ed)., Wanita dalam Percakapan Antar Agama. Yogyakarta: LPKPSM NU, hal 71-94

Gaffar, Afan. 1991. Partisipasi Politik. Prospektif. No.1, Vol.3.

Geertz, Clifford. 1992. Tafsir Kebudayaan. Yogyakarta: Kanisius.

Komisi Pemilihan Umum (KPU) Provinsi Bali. Keanggotaan DPRD Provinsi Periode Tahun 2004-2009

Komisi Pemilihan Umum (KPU) Kabupaten Buleleng. Kenggotaan DPRD Kabupaten Buleleng Periode Tahun 2004-2009

Komisi Pemilihan Umum (KPU) Kabupaten Buleleng. Daftar Calon Tetap (DCT) Anggota Legislatif Kabupaten Buleleng Tahun 2009.
Mosse, Julia Cleves, 1996. Gender dan Pembangunan. Pustaka Pelajar.

Yogyakarta:

Murniati, A. Nunuk Prasetyo.1992. Perempuan Indonesia dan Pola Ketergantungan, dalam Budi Santoso, Sudiarja, Prapadiharja, dan Rika Pratiwi(ed) Citra Wanita dan Kekuasaan (Jawa) Yogyakarta: hal. 19-30.

Muntoro, Soemientoro. 2004. "Hak-hak Kaum Perempuan di Negara Demokrasi". Jurnal Perempuan. Hal 9-13.

Nugroho, Riant. 2008. Gender dan Strategi Pengarusutamaannya di Indonesia. Yogyakarta: Pustaka Pelajar.

Suyanto, Isbodroini.1995. Peranan Sosialisasi Politik terhadap Partisipasi Politik Perempuan, dalam T.O Ihromi (ed) . Kajian Wanita dalam Pembangunan. Jakarta: Yayasan Obor Indonesia.

Surbakti, A. Ramlan.1984. Dasar-dasar IImu Politik. Surabaya. Airlangga University Press.

Undang-Undang No. 10 Tahun 2008 tentang Pemilihan Umum Tahun 2009. Bandung: Citra Utama

Undang-Undang No. 2 Tahun 2008 tentang Partai Politik. Bandung: Citra Umbara. 